\title{
Mathematics Anxiety and Its Relationship with the Achievement of Secondary Students in Malaysia
}

\author{
Puteh M. and Khalin S. Z.
}

\begin{abstract}
This study aims to identify the Mathematics anxiety and its relationship with the achievement of Form Four Students in Perak Tengah district, Malaysia. The design of the study is using quantitative method and the data was collected by using a questionnaire of Student Math Anxiety Scale (SKMP). A total of 190 Form Four students were selected as a research sample. The results showed that the level of mathematics anxiety of the students were at moderate level with $M=2.55$, SD $=0.72$. Analysis of the $t$ test results for gender show that there is no significant difference with $t=\mathbf{- 0 . 8 8 9}, p<0.05$ between the level of mathematics anxiety of female students compared to the male students. The correlation test showed a significant and negative relationship between student's achievement and their mathematics anxiety with correlation value $r=\mathbf{- 0 . 2 3 7}$.
\end{abstract}

Index Terms-Mathematics anxiety, mathematics achievement and student math anxiety scale.

\section{INTRODUCTION}

Extreme Mathematics anxiety which is left unchecked would have negative consequences for students (Arem, 2003; Marzita, 2002). [1], [2] The studies of Effandi (2008), Elenchonthy (2007), Marzita (2002) and Tn.Salwani (2001) have found that the majority of Malaysian students have a moderate level of mathematics anxiety. [2]-[5] According to Hadfield and McNeil (1999), most of the students experiencing mathematics anxiety since elementary school. [6] Arem (1993) and Marzita (2002), have found that there are many factors that brought to the mathematics anxiety such as curriculum weakness, negative experiences in mathematics, pressure and family expectations, teacher's persoanality and teaching style, dreams and expectations of family and peer influences [1], [2].

The study also found that there is an inverse relationship between the level of mathematics anxiety and mathematics performance of students. Tuan Salwani (2001), have found that high level of mathematcs anxiety led to decline of student's achievement with the correlation $r=-0.254$ and $p<$ 0.05 . The finding is consistent with the findings of Effandi and Norazah (2008), study of two semesters of matriculation students have found that there is a significant negative relationship between mathematics anxiety and mathematics performance of students. [3], [5] The finding is also consistent with the findings of Elenchonthy (2007), Fulya (2008) and Marzita (2002). The results show that if students have math anxiety problems, then the student achievement in

Manuscript received August 6, 2014; revised October 20, 2014.

Puteh M. is with the Mathematics Department, Sultan Idris Education University, Malaysia (e-mail: marzita@fsmt.upsi.edu.my).

S. Z. Khalin is with SMK Lambor Kiri, Malaysia (e-mail: Lehe76@yahoo.com.my). mathematics will deteriorate and if the student has less math anxiety level or controlled the mathematics performance is good [2], [4], [7].

\section{LITERATURE REVIEW}

Anxiety according to Freud (1936), is an unpleasant feeling and can cause emotional distress. [8] Tang (1990), defines anxiety as an emotional state when there is fear, anxious and uneasy passions associated with a fear of something. [9] Mathematics anxiety according to Marzita (2002), is a feeling of stressed and anxious when faced with numbers and mathematical problem solving in everyday life or when learning mathematics.[2] Arem (2003), defines math anxiety as a feeling of worry, anxiety, denial, resistance and rejection reactions in mathematics and problem solving. Laurie (1981), expressed as a mathematical anxiety fear, worry, anxious or maybe bored towards mathematics.[10].

According Marzita (2002), mathematics anxiety exist due to various factors such as classroom climate, mathematical abstraction, past experience, the pressure from the family, the experience of being humiliated in front of the class, teaching techniques and so on. The finding is consistent with the findings of Norwood (1994), Arem (2003) and Greenwood (1984) [1], [11], [12].

Extreme anxiety and not controlled, will bring serious consequences to an individual. In terms of mathematics perspection, Arem (2003), Curtain-Philips (1999), Tobias (1995) and Zaslavsky (1994) found that many students are not able to deliver a good performance in mathematics when they are feeling worried or anxious in applying their math skills [1], [13]-[15].

\section{Statement of the Problem}

The decline in performance in mathematics has created anxiety in students and strengthen the perception that they are weak in math. This response will ultimately be a belief that hard to change. According to Hadfield and McNeil (1999), most students experience math anxiety since elementary school. This fear are transferred by school teachers through teaching methods. Traditional methods such as lecturing, teaching basic skills without an emphasis on the concept has been identified as a factors that contribute to mathematics anxiety [6].

Research by Fulya (2008), Elenchoty (2007), Marzita (2002), Tn. Salwani (2001), Arem (1993) and Tobias (1980), has shown that mathematics anxiety had become one of the factors contributing to the decline of the mathematical achievements of the students [1]-[5], [14]. 


\section{IMPORTANCE OF RESEARCH}

Early detection of math anxiety among students is very important so that all those who are in the educational institutions would be able to help students in the control and dealing with the level of math anxiety.

Marzita (2002), have found that the types of questions will also contribute to the presence of math anxiety in students. Knowledge of the types of questions that may lead to students having math anxiety can serve as a guide and considerations required by their teachers to produce teaching and learning process more creative and meaningful [2].

\section{RESEARCH OBJECTIVES}

This study aims to identify the level of mathematics anxiety among form four students in Perak Tengah district, also to determine whether there is a difference math anxiety levels between males and females and to see whether there is a significant relationship between the level of anxiety with mathematics achievement in math exam. This research also focuses on identifying the type of questions that contribute to students' concerns when doing mathematics.

\section{Methodology}

The study used a combination of methods to collect data that is quantitative and qualitative methods. Number of samples used for quantitative studies are 190 respondents, with 86 male students and 104 female students and 5 students for qualitative methods data. The instrument uses a questionnaire SKMP (Student Math Anxiety Scale) which was adopted by the Elenchothy (2007) and SKMP containing 48 items. SKMP is formed based on MAS (Mathematics Anxiety Scale, Fennema \& Sherman, 1976), MARS (Richardson \& Suinn, 1972) and MAQ (Mathematics Anxiety questionnaires, Meece 1981). The instrument uses a 5 -point Likert scale with a range very often (score 5) to never (score 1) in part I and Scale strongly agree (score 5) to strongly disagree (score 1) in part II [16].

Math anxiety levels were divided into three levels, namely low, medium and high. A judgment is made based on a percentage score based on the scores obtained from the findings of SKMP. $20 \%$ scored measured as low, the next $60 \%$ score assessed as moderate and $20 \%$ high level scores as high anxiety levels. The instruments used to measure student's achievement in mathematics is based on the mathematics achievement of students in the midterm 2011 exam. This achievement is graded according to the grading of the MOE (Ministry of Education), A, B, C, D, E and G.

A qualitative study using non-probability sampling which aims sample (purposive sampling). Five students from Form Four students at a secondary school in Perak Tengah district were selected for the study. The samples have moderate and high levels of math anxiety. The instrument used for the qualitative data collected is using triangulation methods namely student journal, questionnaires and structured interviews.

\section{FINDINGS}

This study aims to answer four research questions which are (i) What is the level of math anxiety of Form Four students in Perak Tengah district? (ii) Are there different levels of math anxiety of Form Four students from the gender aspect in Perak Tengah district? (iii) Is there a relationship between mathematics anxiety and mathematics achievement of students in the exam? and (iv) What are the types of questions that contribute to students anxiety when doing mathematics:

1) What is the level of math anxiety of Form Four students in Perak Tengah district?

The results showed that the level of mathematics anxiety of students are at a moderate level (mean $=2.55, \mathrm{SD}=0.72)$. In detail all dimensions of math anxiety construct also at a moderate level with a mean range of 2.28 to 2.83 and standard deviations range of 0.74 to 1.11 (see Table I)

\begin{tabular}{ccc}
\multicolumn{3}{c}{ TABLE I: DESCRIPTIVE ANALYSIS OF MATHEMATICS ANXIETY DIMENSION } \\
\hline Dimensions of mathematics anxiety & Mean & $\begin{array}{c}\text { Standard } \\
\text { Division }\end{array}$ \\
\hline Climate math class & 2.28 & 0.86 \\
mathematical incompetence & 2.52 & 0.74 \\
mathematical abstraction & 2.56 & 0.82 \\
mathematics test & 2.83 & 1.11 \\
\hline
\end{tabular}

2) Are there different levels of math anxiety of Form Four students from the gender aspect in Perak Tengah district?

The result of the t-test shown in Table II, showed no significant difference $t=-0889 ; p>0.05$ between the level of mathematics anxiety of boys and girls. This indicates that the level of mathematics anxiety of Form Four students in Perak Tengah district is not affected in terms of gender, male or female students have the same level of anxiety that is at a moderate level.

TABLE II: T-TEST COMPARISON OF ANXIETY LEVELS BY GENDER.

\begin{tabular}{lllllc}
\hline gender & $\mathrm{N}$ & Mean & Sd & t-test & Sig 2-tailed \\
\hline Boy & 86 & 2.499 & 0.732 & -0.889 & 0.375 \\
Girl & 104 & 2.591 & 0.705 & & \\
\hline
\end{tabular}

3) Is there a relationship between mathematics anxiety and mathematics achievement of students in the exam?

Table III shows that there is a significant inverse relationship between mathematics anxiety and mathematics achievement of students with $\left.r_{(190)}=-0237\right), p=0.001$ $(p<0.01)$. This indicates that students who have high anxiety exhibit low achievement in mathematics and vice versa.

TABLE III: CORRELATION LEVEL BETWEEN MATH ANXIETY AND MATH STUDENT ACHIEVEMENT

\begin{tabular}{|c|c|c|c|c|}
\hline & & & $\begin{array}{l}\text { Student Math } \\
\text { Anxiety }\end{array}$ & $\begin{array}{l}\text { Student Math } \\
\text { Achievement }\end{array}$ \\
\hline \multirow[t]{2}{*}{$\begin{array}{l}\text { Student } \\
\text { Anxiety }\end{array}$} & Math & $\begin{array}{l}\text { Correlation of } \\
\text { Spearman Rho } \\
\text { Sig (2 hala) }\end{array}$ & 1.00 & $\begin{array}{l}-0.237 * * \\
0.001\end{array}$ \\
\hline & & $\mathrm{N}$ & 190 & 190 \\
\hline \multirow[t]{2}{*}{$\begin{array}{l}\text { Student } \\
\text { Achievement }\end{array}$} & Math & $\begin{array}{l}\text { Correlation of } \\
\text { Spearman Rho } \\
\text { Sig }(2 \text { hala })\end{array}$ & $\begin{array}{l}-0.237 * * \\
0.001\end{array}$ & 1.00 \\
\hline & & $\mathrm{N}$ & 190 & 190 \\
\hline
\end{tabular}

** Correlation is significant at 0.01 (2-way) 
4) What are the types of questions that contribute to students anxiety when doing mathematics?

The results showed that the type of questions also contributed to mathematics anxiety in students in doing math. There is fear in the students for the questions in the algebra form and mathematical word compared to abstract questions and activities question activities. There are anxiety symptoms in students when answering these types of questions such as sweating, dizziness, nervousness and increased heart rate. Students feel comfortable and enjoyed when answering activities involving questions pattern because students do not bound by mathematical concepts and the direct application of these activities also provide an opportunity for students to explore and be creative in solving problems on the math. However, for students who do not like to follow directions, they will be a little bit difficult to read and understand and follow the instructions provided.

\section{DISCUSSION}

The results showed that the level of mathematics anxiety of Form Four students in Perak Tengah district is at moderate level. The finding is consistent with the findings of Tn. Salwani (2001), Elenchonthy (2007) and Fulya (2008). The study of different levels of math anxiety in terms of gender finds that there is no difference between the anxiety level of male students and female students. [4]-[7]The finding is consistent with the findings of Miller (2001) and Tapia and Marsh (2004) where they found that math anxiety has nothing to do with gender [17], [18].

There is a negative relationship between mathematics anxiety and mathematics achievement in which students with high math anxiety would show poor mathematics performance and vice versa. Although the correlation is low but significantly correlated. Therefore, the parties concerned with education directly or indirectly should take early steps in dealing with these issues so that math anxiety can be controlled. The finding is consistent with the findings of Hadfield \& Mc Neil (1993), Ashcraft \& kirk (2001), Bower (2001), Tapia and Marsh (2004) and Elenchothy (2007), [4], [6], [18]-[20].

The study has found that the types of questions also influence the level of anxiety of students in doing math. The type of question in the form of games or activities which are free-form can generate students creativity and also helps to reduce students' anxiety when doing mathematics. According to Marzita (2002), questions in the form of games can contribute a sense of excitement, tranquility and comfort to the students to complete the activity as they are free to speak, to talk with each other, joking and produce their own ideas with their peers while solving math problems given [2].

\section{RESEARCH IMPLICATION}

Teachers need to be concerned about the effects of math anxiety on math achievement of students. They have applied the knowledge and skills to reduce and control the level of their students' concerns by establishing teaching and learning environment that is able to invite a sense of excitement and fun for students to learn and interactive teaching and learning environment that is conducive.Woodard (2004), propose a number of techniques that can reduce the students' anxiety levels such as (i) create an excellent learning environment and create excitement in students and avoid a stressful environment in the students. (ii) Using techniques in cooperative groups. This can help students reduce their anxiety because they are working in a group who shared the same problem. (iii) Teach students according to their ability and using effective teaching tools [21].

Tang (1990), also suggested a number of ways that can be practiced by the teacher to help reduce anxiety in students which is (i) Give encouragement and praise to the students so that they can build their confidence and encourage them in a positive way. (ii) Reduce the threat. Avoid using threatening words and intimidate the students. (iii) Showing love, warmth, trust, empathy and acceptance for students and (iv) provide rehabilitation to the less advanced students [9].

\section{REFERENCES}

[1] C. Arem, Conquering Math Anxiety: a Self-Help Workbook, California: Brooks/Col Thomasan Learning, 1993.

[2] M. Puteh, Factors Associated with Mathematics Anxiety, Tanjong Malim: Penerbitan Universiti Pendidikan Sultan Idris, 2002.

[3] E. Zakaria and N. M. Noh, "The effects of mathematics anxiety on matriculation students as related to motivation and achievement," Eurasia Journal of Mathematics, Science and Technology Education, vol. 4, no. 1, pp. 27-30, 2008.

[4] E. Davrajoo, "Kebimbangan matematik dan hubungan pencapaian pelajar tingkatan empat di Daerah Klang," Malaysia, Master Thesis, Universiti Putra Malaysia, 2007.

[5] T. S. A. Salleh, "Perkaitan Antara kerisauan matematik dengan pencapaiannya di sebuah institusi pengajian Tinggi Teknikal," Unpublished Thesis Universiti Kebangsaan Malaysia, Bangi, Kuala Lumpur, 2001

[6] H. McNeil, "The relationship between Myers-Briggs personality type and mathematics anxiety among preservice elementary teachers," Journal of Instructional Psychology, vol. 21, no. 4, pp. 375-384, 1999.

[7] Y. S. Fulya, "Mathematics anxiety among $4^{\text {th }}$ and $5^{\text {th }}$ grade Turkish lementary school students," International Electronic Journal of Mathematics Education, vol. 3 no. 3, 2008.

[8] S. Freud, The Problem of Anxiety, New York: Norton, 1936.

[9] C. Y. Tang, Psikologi Perkembangan Siri Pendidikan Perguruan, Kumpulan Budiman Sdn. Bhd. Selangor, 1990.

[10] L. Buxton, Do You Panic About Maths?-Coping With Maths Anxiety, Heinemann Educational Publishers, 1981.

[11] K. S. Norwood, "The effect of instructional approach on mathematics anxiety and achievement," School Science and Mathematics, vol. 94, no. 5 , pp. 248-254, 1994.

[12] J. Greenwood, "My anxiety about math anxiety," Mathematics Teacher, vol. 77, no. 9, pp. 662-664, 1984.

[13] M. C. Philips, Math Attack: How to Reduce Math Anxiety in the classroom, at Work and in Everyday Personal, New York: Norton, 1999.

[14] S. Tobias, "Math anxiety: What can we do about it," Today's Education, vol, 69, pp. 26-29, 1980.

[15] C. Zaslavsky, Fear of Math: How to Get Over it and Get on with Your life, New Brunswick: Rutgers University Press, 1994.

[16] F. C. Richardson and R. M Suinn, "The mathematics anxiety rating scale," Journal of Counseling Psychology, vol. 19, pp. 551-554, 1972.

[17] L. D. Miller and C. E. Mitchell, "Mathematics anxiety and alternative methods of evaluation," Journal of Instructional Psychology, vol. 21, no. 4, pp. 353-358, 1994.

[18] M. Tapia, "An Instruments to measure mathematics attitudes," Academic Exchange Quaterly, vol. 8, no. 2, pp. 1-8, 2003.

[19] M. H. Ashcraft and E. P. Kirk, "The relationship among working memory, math anxiety, and performance," Journal of Experimental Psychology, vol. 130, no. 2, pp. 224-237, 2001.

[20] B. Bowers, "Math fears subtract from memory, learning," Science News, vol. 159, no. 26, p. 405, 2001. 
[21] T. Woodard, "The effects of math anxiety on post-secondary development students as related to achievement," Gender and Age, Inquiry, vol. 9, no. 1, 2004

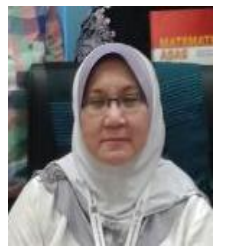

Marzita Puteh was born in Malacca, Malaysia on March 21, 1960. She took his bachelor's degree University of Reading, UK in 1983 with majoring in mathematics. In 1992, she obtained her master in education (UKM) and her Ph.D in 1999 from University of East Anglia, Norwich, England. She is currently a professor at Mathematics Department, Sultan Idris Education University. Her research interests include the affective domain of teaching and learning mathematics and focusing on mathematics anxiety. She is a competent, efficient and resourceful researcher with enviable research outputs. She has published several books pertaining to mathematics and teaching and learning mathematics.

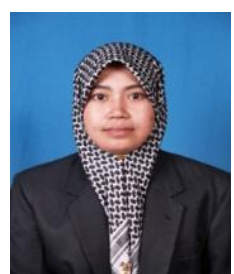

Siti Zaleha Binti Khalin was born at Parit, Perak on December 26, 1976. She was obtained her bachelor of education (mathematics) with honours in 2007 and finishes her master of education in mathematics in 2014. She has been a mathematics teacher at SMK Tandek, Kota Marudu Sabah for 6 years before moving to SMK. Lambor Kiri, Perak since 2006. She obtained the certificate of teaching mathematics for Secondary School in 1999 from Maktab Perguruan Tuanku Bainun, Pulau Pinang. She has taught mathematics for Secondary School for thirteen years and was awarded the excellent service award in 2004 and 2010 